\title{
Organic aerosol volatility and viscosity in the North China Plain: contrast between summer and winter
}

\author{
Weiqi Xu ${ }^{1}$, Chun Chen ${ }^{1,2}$, Yanmei Qiu ${ }^{1,2}$, Ying Li $^{1}$, Zhiqiang Zhang ${ }^{1,2}$, Eleni Karnezi ${ }^{3, a}$, Spyros N. Pandis ${ }^{3}$, \\ Conghui Xie ${ }^{1,2, b}$, Zhijie $\mathbf{L i}^{1,2}$, Jiaxing Sun ${ }^{1,2}$, Nan $\mathrm{Ma}^{4}$, Wanyun $\mathrm{Xu}^{5}$, Pingqing Fu ${ }^{2,6}$, Zifa Wang ${ }^{1,2}$, Jiang Zhu ${ }^{1}$, \\ Douglas R. Worsnop ${ }^{7}$, Nga Lee $\mathbf{N g}^{8,9,10}$, and Yele Sun ${ }^{1,2,11}$ \\ ${ }^{1}$ State Key Laboratory of Atmospheric Boundary Layer Physics and Atmospheric Chemistry, Institute of Atmospheric \\ Physics, Chinese Academy of Sciences, Beijing 100029, China \\ ${ }^{2}$ College of Earth and Planetary Sciences, University of Chinese Academy of Sciences, Beijing 100049, China \\ ${ }^{3}$ Department of Chemical Engineering, Carnegie Mellon University, Pittsburgh, PA 15213, USA \\ ${ }^{4}$ Institute for Environmental and Climate Research, Jinan University, Guangzhou, 511443, China \\ ${ }^{5}$ State Key Laboratory of Severe Weather \& Key Laboratory for Atmospheric Chemistry, Institute of Atmospheric \\ Composition, Chinese Academy of Meteorological Sciences, Beijing, 100081, China \\ ${ }^{6}$ Institute of Surface-Earth System Science, Tianjin University, Tianjin, 300072, China \\ ${ }^{7}$ Aerodyne Research Inc., Billerica, MA 01821, USA \\ ${ }^{8}$ School of Earth and Atmospheric Sciences, Georgia Institute of Technology, Atlanta, GA 30332, USA \\ ${ }^{9}$ School of Chemical and Biomolecular Engineering, Georgia Institute of Technology, Atlanta, GA 30332, USA \\ ${ }^{10}$ School of Civil and Environmental Engineering, Georgia Institute of Technology, Atlanta, GA 30332, USA \\ ${ }^{11}$ Center for Excellence in Regional Atmospheric Environment, Institute of Urban Environment, \\ Chinese Academy of Sciences, Xiamen, 361021, China \\ ${ }^{a}$ now at: Earth Sciences Department, Barcelona Supercomputing Center, BSC-CNS, Barcelona 08034, Spain \\ b now at: State Key Joint Laboratory of Environmental Simulation and Pollution Control, College of Environmental Sciences \\ and Engineering, Peking University, Beijing, 100871, China
}

Correspondence: Yele Sun (sunyele@mail.iap.ac.cn)

Received: 22 October 2020 - Discussion started: 4 December 2020

Revised: 6 February 2021 - Accepted: 3 March 2021 - Published: 8 April 2021

\begin{abstract}
Volatility and viscosity have substantial impacts on gas-particle partitioning, formation and evolution of aerosol and hence the predictions of aerosol-related air quality and climate effects. Here aerosol volatility and viscosity at a rural site (Gucheng) and an urban site (Beijing) in the North China Plain (NCP) in summer and winter were investigated by using a thermodenuder coupled with a highresolution aerosol mass spectrometer. The effective saturation concentration $\left(C^{*}\right)$ of organic aerosol $(\mathrm{OA})$ in summer was smaller than that in winter $\left(0.55 \mu \mathrm{g} \mathrm{m}^{-3}\right.$ vs. $0.71-$ $0.75 \mu \mathrm{g} \mathrm{m}^{-3}$ ), indicating that $\mathrm{OA}$ in winter in the NCP is more volatile due to enhanced primary emissions from coal combustion and biomass burning. The volatility distributions varied and were largely different among different $O A$ factors. In particular, we found that hydrocarbon-like OA (HOA)
\end{abstract}

contained more nonvolatile compounds compared to coalcombustion-related OA. The more oxidized oxygenated OA (MO-OOA) showed overall lower volatility than less oxidized OOA (LO-OOA) in both summer and winter, yet the volatility of MO-OOA was found to be relative humidity $(\mathrm{RH})$ dependent showing more volatile properties at higher RH. Our results demonstrated the different composition and chemical formation pathways of MO-OOA under different $\mathrm{RH}$ levels. The glass transition temperature $\left(T_{\mathrm{g}}\right)$ and viscosity of $\mathrm{OA}$ in summer and winter are estimated using the recently developed parameterization formula. Our results showed that the $T_{\mathrm{g}}$ of OA in summer in Beijing $(291.5 \mathrm{~K})$ was higher than that in winter $(289.7-290.0 \mathrm{~K})$, while it varied greatly among different OA factors. The viscosity suggested that OA existed mainly as solid in winter in Beijing 
$(\mathrm{RH}=29 \pm 17 \%)$, but as semisolids in Beijing in summer $(\mathrm{RH}=48 \pm 25 \%)$ and Gucheng in winter $(\mathrm{RH}=68 \pm 24 \%)$. These results have the important implication that kinetically limited gas-particle partitioning may need to be considered when simulating secondary OA formation in the NCP.

\section{Introduction}

Organic aerosol (OA) accounts for a substantial mass fraction of atmospheric fine particulate matter (Jimenez et al., 2009). However, the simulation results (e.g., concentrations and oxidation states) from chemical transport models often fail to agree with the observations to a certain degree (Matsui et al., 2009; Chen et al., 2011), which is partly due to our limited understanding of the chemical mechanisms, reaction rates and lifetime of OA. Volatility and viscosity are two important properties of OA. They have substantial impacts on the gas-particle partitioning of oxidized compounds (Shiraiwa and Seinfeld, 2012; Liu et al., 2018) and consequently the formation and evolution of $\mathrm{OA}$, which further contributes to the uncertainty in predictions of aerosol-related air quality and climate effects (Glasius and Goldstein, 2016; Shrivastava et al., 2017).

The OA volatility can be quantified by various approaches. Compared to the estimations from elemental formulas and measured partitioning of gas or particle species, thermogram analysis was found to be the most reproducible (Stark et al., 2017). As a result, the thermodenuder (TD) combined with a high-resolution time-of-flight aerosol mass spectrometer (HR-AMS) has been widely used for the quantification of OA volatility. Laboratory research has characterized the volatility of specific secondary OA (SOA) and the effect of temperature and relative humidity $(\mathrm{RH})$. For example, the evaporation kinetics of limonene SOA particles at low $\mathrm{RH}$ levels $(<5 \%$ and $50 \%$ ) are nearly the same, while a slightly larger fraction evaporates at higher RH (90\%) (Wilson et al., 2015; Lee et al., 2011b). Zaveri et al. (2020) found that the aged $\alpha$-pinene SOA had a higher volume fraction remaining (VFR) than fresh SOA under a higher TD temperature. Compared with laboratory experiments, the oxidation pathways and oxidants are far more complex in ambient air, and the oxygenated products can be composed of hundreds or even thousands of species with a wide range of volatilities. Previous field observations on volatility distributions of OA have mainly been focused on Europe and the US under low $\mathrm{NO}_{x}$ levels (Xu et al., 2016; Louvaris et al., 2017a; Saha et al., 2017; Kostenidou et al., 2018). Lee et al. (2011a) found that $\mathrm{NO}_{x}$ can have a large impact on the volatility of SOA in a chamber experiment, suggesting that the OA volatilities in high- $\mathrm{NO}_{x}$ and high particulate-matter (PM) environments, e.g., the North China Plain (NCP), need to be further investigated. The volatility of $\mathrm{OA}$ also presents strong seasonal variations. For example, Huang et al. (2019) found that $\mathrm{OA}$ in winter is less volatile than that in summer in Germany. The volatility of cooking OA (COA) and hydrocarbon-like OA (HOA) at the same sampling site varied substantially between summer and winter (Saha et al., 2018; Paciga et al., 2016). These differences can be attributed to the differences in source emissions, precursors and temperature (Schervish and Donahue, 2020). To our knowledge, the volatility of OA has only been characterized in summer in the NCP (Xu et al., 2019; Qiao et al., 2020), and the observations in urban and rural areas during wintertime are very limited. In addition, previous studies investigated the volatility of primary OA (POA) including biomass burning, traffic and cooking emissions (May et al., 2013a, b, c; Takhar et al., 2019); however, the measurements of coal combustion OA (CCOA), a dominant factor of POA in the NCP (Wang et al., 2019), are rare. Failing to consider the contributions of intermediate-volatility organic compounds (IVOCs) and semi-VOCs (SVOCs) from such POA factors may lead to the underestimation of SOA concentration in models. In addition, many studies show that not all aerosols evaporate even after heating to high temperatures (i.e., $230-300^{\circ} \mathrm{C}$ ) (Massoli et al., 2015; Xu et al., 2016). Those nonvolatile compounds can contribute to new particle formation and subsequent growth (Wehner et al., 2004; Xu et al., 2016; Massoli et al., 2015; Wang et al., 2017). Despite the increasing interest in nonvolatile particles, our understanding of this type of nonvolatile particles is incomplete, especially in highly polluted environments.

The OA volatility is intrinsically related to particle phase state, which plays an important role in affecting heterogeneous reactions and the formation of cloud condensation nuclei. Particle phase states have been measured by using a three-arm impactor (Liu et al., 2017, 2019) and polarization lidar (Tan et al., 2020) in China in recent years. The results showed that particles are generally in liquid state throughout the year in south China, while there is a transition from semisolid to liquid state as RH increases above $60 \%$ in winter in the NCP. However, these studies measured the phase state of bulk aerosol, which is generally dominated by hygroscopic secondary inorganic species; our knowledge of the OA phase state and viscosity remains limited. Some methods have been developed to estimate OA phase state based on the molar mass, molecular atomic oxygen-to-carbon ratio $(\mathrm{O} / \mathrm{C})$ of SOA components and the number of carbon, hydrogen and oxygen atoms (Shiraiwa et al., 2017; DeRieux et al., 2018). However, the effects of molecular structure and functional groups on glass transition temperature $\left(T_{\mathrm{g}}\right)$, a parameter determining a phase transition between amorphous solid and semisolid states, are not considered in these studies. Recently, the close relation between volatility and viscosity have been proved (Zhang et al., 2019; Champion et al., 2019), and parameterizations have been developed to predict viscosity based on $\mathrm{O} / \mathrm{C}$ and volatility at 11 global sites ( $\mathrm{Li}$ et al., 2020). However, the simulation of the phase state and viscosity of OA in the NCP during wintertime has not yet 
been made, impeding our understanding of the phase states of OA and its potential impacts.

In this study, an HR-AMS coupled with a TD was deployed in summer and winter at an urban site in Beijing and a rural site in winter in the NCP to investigate the differences in OA volatilities in different seasons and chemical environments. The volatility distributions of primary and secondary $\mathrm{OA}$ factors are estimated, and the impacts of $\mathrm{RH}$ are elucidated. Further, the glass transition temperature and viscosity of OA at urban and rural sites are estimated by using the recently developed parameterization, and their implications in phase state and gas-particle partitioning are demonstrated.

\section{Experimental methods}

\subsection{Measurements}

The measurements were conducted at an urban site (Institute of Atmospheric Physics, $39^{\circ} 58^{\prime} \mathrm{N}, 116^{\circ} 22^{\prime} \mathrm{E}$ ), from 20 May to 23 June 2018 and from 20 November to 25 December 2018, and a rural site (Gucheng in Hebei province, $39^{\circ} 09^{\prime} \mathrm{N}, 115^{\circ} 44^{\prime} \mathrm{E}$ ) from 10 December 2019 to 13 January 2020. A detailed description of the two sampling sites is given in $\mathrm{Xu}$ et al. (2015) and Sun et al. (2020). Ambient particles passed through a $\mathrm{PM}_{2.5}$ cyclone and a Nafion dryer, where aerosol particles larger than $2.5 \mu \mathrm{m}$ were filtered and the remaining particles were dried. After that, aerosol particles were sampled into an HR-AMS by switching between the TD and bypass line every $15 \mathrm{~min}$. The settings of the TD heating temperature were $50,120(150)$ and $250^{\circ} \mathrm{C}$ in the summer and winter of 2018 in Beijing. In addition, the data during the temperature ramping were also included. In total, TD data with seven temperature gradients were obtained in Beijing. By contrast, the TD temperature was set to increase linearly in winter at the Gucheng site, leading to more data points across different temperatures. The residence time (RT) of aerosol particles in TD was $7.4 \mathrm{~s}$ in the summer of 2018 and $10 \mathrm{~s}$ in the winters of 2018 and 2019 due to different plug flow rate. The TD loss $(90 \%)$ was calibrated using aerosolized $\mathrm{NaCl}$ following the methods described by Huffman et al. (2008).

\subsection{AMS data analysis}

The HR-AMS data were analyzed by PIKA (V 1.62F). The ionization efficiency (IE) and relative ionization efficiencies (RIEs) of ammonium and sulfate were calibrated following the standard protocols (Jayne et al., 2000). The compositiondependent collection efficiency was applied for the ambient data, while a constant value (0.5) was used for the TD data (Huffman et al., 2009). All elemental ratios of OA in this study were calculated by the "Improved-Ambient (I-A)" method (Canagaratna et al., 2015) unless specified. The combined data from bypass and TD lines ( $\mathrm{MS}_{\text {bypass+TD }}$ ) were analyzed with positive matrix factorization (PMF) to resolve potential OA factors (Ulbrich et al., 2009). Four factors were identified in the summer of 2018: HOA, COA, less oxidized oxygenated OA (LO-OOA) and more oxidized OOA (MOOOA). In the winter of 2018 in Beijing, fossil-fuel-related OA (FFOA) and oxidized POA (OPOA) were also identified in addition to the COA, LO-OOA and MO-OOA. Compared with Beijing, four OA factors - HOA, coal combustion OA (CCOA), biomass burning OA (BBOA) and OOA - were identified at the Gucheng site in winter. It should be noted that FFOA in winter in Beijing refers to the mixed HOA and CCOA which cannot be separated by PMF. A detailed description of the source apportionment of OA at the two sites is given in Xu et al. (2019) and Chen et al. (2021).

\subsection{Estimation of $\mathrm{OA}$ volatility distribution}

A detailed description of the estimation of the atmospheric organic aerosol volatility distribution is given in Karnezi et al. (2014). Briefly, six logarithmically spaced effective saturation concentration $\left(C^{*}\right)$ bins with a maximum value of $100 \mu \mathrm{g} \mathrm{m}^{-3}$ are used to fit the measured thermograms since there is little information on the partitioning of compounds with $C^{*} \geq 1000 \mu \mathrm{gm}^{-3}$ due to the average OA concentration being $13-23 \mu \mathrm{g} \mathrm{m}^{-3}$ in this study. In addition, six discrete values of vaporization enthalpy and accommodation coefficient were used, i.e., 20, 50, 80, 100, 150 and $200 \mathrm{~kJ} \mathrm{~mol}^{-1}$ and $0.01,0.05,0.1,0.2,0.5$ and 1 , respectively (Karnezi et al., 2014). The choice of $C^{*}$ bins depends on the best fits between the measured and predicted thermogram. In this study, the combinations of all properties with the smallest error (top $1 \%$ ) were identified as "best estimate". The predicted and absolute thermograms are shown in Figs. S1-S2. The mass fraction of each $C^{*}$ bin ranged from 0 to 1 with a step of 0.1 .

\subsection{Predictions of glass transition temperature and viscosity}

A detailed description of predicting the glass transition temperature, viscosity and some parameters of $\mathrm{OA}$ is given in $\mathrm{Li}$ et al. (2020). Briefly, $T_{\mathrm{g}, i}$ for each volatility bin is predicted based on volatility and $\mathrm{O} / \mathrm{C}$ (Aiken ambient method) using Eq. (1).

$$
\begin{aligned}
T_{\mathrm{g}, i} & =289.10-16.50 \times \log _{10}\left(C_{i}^{0}\right)-0.29 \\
& \times\left[\log _{10}\left(C_{i}^{0}\right)\right]^{2}+3.23 \times \log _{10}\left(C_{i}^{0}\right)(\mathrm{O} / \mathrm{C})
\end{aligned}
$$

The term $C^{0}$ here refers to $C^{*}$ based on the assumption of ideal thermodynamic mixing (Donahue et al., 2011). The glass transition temperatures of organic aerosols under dry conditions $\left(T_{\mathrm{g} \text {,org }}\right)$ are calculated by the GordonTaylor equation assuming a Gordon-Taylor constant $\left(k_{\mathrm{GT}}\right)$ of 1 (Dette et al., 2014).

$$
T_{\mathrm{g}, \mathrm{org}}=\sum_{i} \omega_{i} T_{\mathrm{g}, i}
$$


where $\omega_{i}$ is the mass fraction in the particle phase for each volatility bin.

The $T_{\mathrm{g}}$ of organic-water mixtures $\left(T_{\mathrm{g}}\left(\omega_{\text {org }}\right)\right)$ at a given RH can be estimated using the Gordon-Taylor equation:

$$
T_{\mathrm{g}}\left(\omega_{\text {org }}\right)=\frac{\left(1-\omega_{\text {org }}\right) T_{\mathrm{g}, \mathrm{w}}+\frac{1}{k_{\mathrm{GT}}} \omega_{\mathrm{org}} T_{\mathrm{g}, \text { org }}}{\left(1-\omega_{\mathrm{org}}\right)+\frac{1}{k_{\mathrm{GT}}} \omega_{\text {org }}},
$$

where $T_{\mathrm{g}, \mathrm{w}}$ is the glass transition temperature of pure water $(136 \mathrm{~K})$ and $k_{\mathrm{GT}}$ is the Gordon-Taylor constant for organicwater mixtures, which is suggested to be 2.5. $\omega_{\text {org }}$ is the mass fraction of organics in particles of organic-water mixtures, and the water content in OA can be estimated using the effective hygroscopicity parameter $(\kappa)$, which is calculated by the method in Lambe et al. (2011) and Mei et al. (2013) marked as $\kappa$ (Lambe) and $\kappa\left(f_{44}\right)$, respectively.

Viscosity can then be estimated by applying the VogelTammann-Fulcher equation $\eta=\eta_{\infty} e^{\frac{T_{0} D}{T-T_{0}}}$, where $\eta_{\infty}$ is the viscosity at infinite temperature $\left(10^{-5} \mathrm{Pas}\right), D$ is the fragility parameter which is assumed to be 10 and $T_{0}$ is the Vogel temperature calculated as $T_{0}=\frac{39.17 T_{\mathrm{g}}}{D+39.17}$. When $T_{\mathrm{g}}\left(\omega_{\text {org }}\right)$ is larger than ambient $T$, particles are regarded as solid.

The characteristic timescale of mass transport and mixing by molecular diffusion $\left(\tau_{\text {mix }}\right)$ is also calculated: $\tau_{\text {mix }}=$ $d_{\mathrm{p}}^{2} /\left(4 \pi^{2} D_{\mathrm{b}}\right)$, where $d_{\mathrm{p}}$ is the particle diameter (assuming $200 \mathrm{~nm}$ here), and the bulk diffusion coefficient $D_{\mathrm{b}}$ is calculated from the predicted viscosity by the fractional StokesEinstein relation: $D=D_{C}\left(\frac{\eta_{C}}{\eta}\right)^{\xi}$, where $\xi$ is an empirical fit parameter and $\xi=0.93$. $\eta_{C}$ is the viscosity at which the Stokes-Einstein relation and fractional Stokes-Einstein relation predict the same diffusion coefficient.

\section{Results and discussion}

\subsection{Volatility of aerosol species}

Figure 1 shows the thermograms of non-refractory submicron $\left(\mathrm{NR}-\mathrm{PM}_{1}\right)$ species at both urban and rural sites. The remaining organics loading in Gucheng was lower than that in Beijing under the same TD temperature during wintertime, particularly at $T>150^{\circ} \mathrm{C}$, suggesting that $\mathrm{OA}$ in Gucheng was overall more volatile than those at urban sites. Such differences can be reasonably attributed to the different OA composition at the two sites. For example, OA at the rural site presented much higher contributions from coal combustion and biomass burning emissions than that at the urban site (Sun et al., 2020). Further, SOA composition could also be different. While photochemical aqueous-phase reactions was found to play an important role in SOA formation in Gucheng (Kuang et al., 2020), both photochemical and aqueous-phase production were important in Beijing (Xu et al., 2017). Despite a shorter TD residence time in summer, more remaining nitrate was observed which was more likely caused by the less volatile nitrate, (e.g., organic nitrate
(ON) that cannot be distinguished from inorganic nitrate with AMS). By using the $\mathrm{NO}_{x}$ method (Farmer et al., 2010), we estimated that $\mathrm{ON}$ can account for $11 \%-27 \%$ of total nitrate in summer (Xu et al., 2020), while their contributions were negligible during wintertime in both Gucheng and Beijing. Such seasonal differences in ON are in good accordance with previous observations in China (Yu et al., 2019), emphasizing the role of $\mathrm{ON}$ in summer. There was $40 \%$ of the residual mass of chloride in summer after heating at $T>200^{\circ} \mathrm{C}$, which is larger than that in winter at both urban and rural sites $(4 \%-8 \%)$. Such different residual loadings are likely due to the different sources of chloride, which were mainly associated with biomass burning and coal combustion emissions in winter, while a considerable fraction existed in the form of less volatile chloride salts (e.g., $\mathrm{KCl}$ ) in summer.

At $T>150^{\circ} \mathrm{C}$, sulfate in Gucheng showed the lowest residual mass compared to that in Beijing, while the behaviors are contrary at $T<150^{\circ} \mathrm{C}$. One explanation is that the different formation mechanisms (gas-phase, heterogeneous or aqueous-phase chemistry) led to the variations in mixed state which could affect the thermograms of sulfate during three campaigns. The different contribution of organosulfate (OS) compounds with a different volatility to total $\mathrm{SO}_{4}$ is another possible reason, which is supported by the fact that the particles under a different TD temperature fell into different regions in a triangle-shaped space (Fig. S3) defined by Chen et al. (2019) for organic and inorganic sulfate species. All these differences in aerosol volatility between urban and rural sites emphasize the influence of nonvolatile inorganic components on species measured by HR-AMS.

\subsection{Volatility of OA species}

OA was dominated by SOA in summer in Beijing (72\%), and the contribution was much higher than that in winter in Beijing (42\%) and Gucheng (51\%), in agreement with previous studies (Zhou et al., 2020). The $C^{*}$ of OA in summer was $0.55 \mu \mathrm{g} \mathrm{m}^{-3}$ in Beijing, which is smaller than that in winter in Beijing $\left(0.71 \mu \mathrm{g} \mathrm{m}^{-3}\right)$ and Gucheng $\left(0.75 \mu \mathrm{g} \mathrm{m}^{-3}\right)$, indicating the more volatile nature of $\mathrm{OA}$ in winter. One explanation was the higher contributions of POA in winter, which is generally more volatile than SOA (Huffman et al., 2009). This feature is contrasts with Germany (Huang et al., 2019), where organics are found to be more volatile in summer. Such a discrepancy is likely due to the different OA compositions in different chemical environments. Support for this possibility is a higher $\mathrm{O} / \mathrm{C}$ of $\mathrm{OA}$ in Germany but a lower $\mathrm{O} / \mathrm{C}$ in Beijing during wintertime compared to summer. Enhanced primary emission sources in winter with relatively high volatility are another possible cause.

Despite HOA, CCOA and FFOA all being related to fossil fuel, they differ in the order of volatility between urban and rural sites. HOA in Beijing showed a lower saturation concentration compared to that in Gucheng $\left(C^{*}=0.75 \pm 0.56\right.$ vs. $0.93 \pm 0.69 \mathrm{\mu g} \mathrm{m}^{-3}$ ), while the $C^{*}$ of FFOA in Bei- 


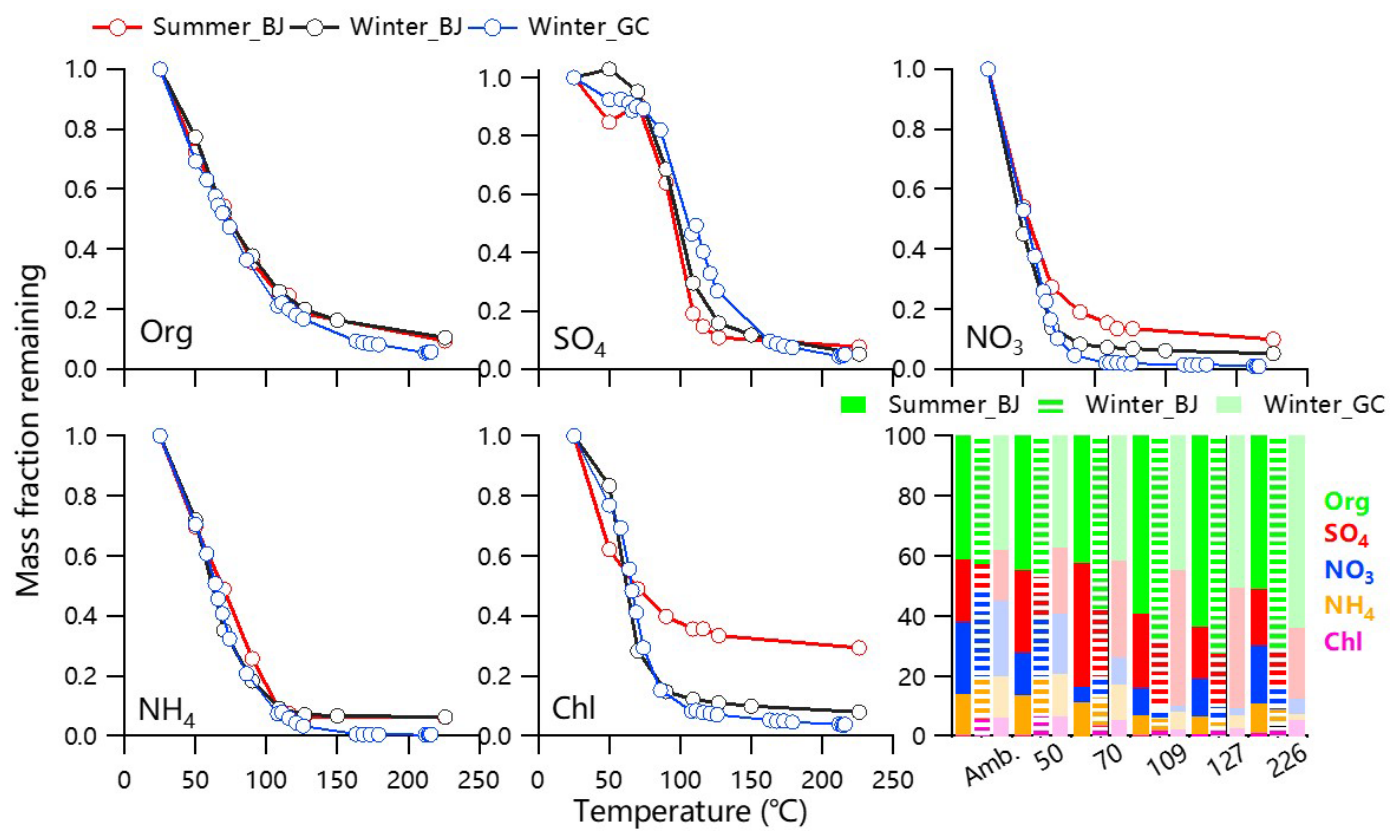

Figure 1. Thermograms of non-refractory submicrometer aerosol species including organics $(\mathrm{Org})$, sulfate $\left(\mathrm{SO}_{4}\right)$, nitrate $\left(\mathrm{NO}_{3}\right)$, ammonium $\left(\mathrm{NH}_{4}\right)$ and chloride $(\mathrm{Chl})$. The mass fractions of size-resolved non-refractory submicrometer aerosol (NR-PM 1 ) species as a function of TD temperature are also shown.

jing was relatively higher compared to that of CCOA in Gucheng $\left(1.41 \pm 1.01\right.$ vs. $\left.0.86 \pm 0.75 \mu \mathrm{g} \mathrm{m}^{-3}\right)$, corresponding to the lower mass fraction remaining (MFR) at the same TD temperature (Fig. 2). One reason was likely the different quality of fuels used at urban and rural sites. Another reason could be the fact that FFOA in Beijing was mainly from regional transport and was aged before arriving in Beijing. FFOA and CCOA showed lower remaining loadings ( 1\%) compared to HOA $(8 \%-10 \%)$ at $T>200^{\circ} \mathrm{C}$, implying that HOA contained more nonvolatile compounds. Polycyclic aromatic hydrocarbons (PAHs, compounds dominantly from coal combustion, which were determined with the approach recommended by Dzepina et al., 2007) showed a contribution of SVOCs by $60 \%-71 \%$, consistent with the high contributions of fossil sources to more volatile organic aerosol based on a radiocarbon-based $\left({ }^{14} \mathrm{C}\right)$ approach $(\mathrm{Ni}$ et al., 2019). It should be noted that OA factors related to fossil fuel combustion also showed a considerable contribution of extremely low-volatility compounds (ELVOCs with $\left.C^{*} \leq 10^{-4} \mu \mathrm{g} \mathrm{m}^{-3}\right)(5 \%-13 \%)$, which is comparable to that in Paris (11\%) (Paciga et al., 2016).

The fraction of low-volatility compounds (LVOCs) in $\mathrm{COA}$ in winter $(44 \%)$ is slightly higher than that in summer $(40 \%)$ in Beijing, which fell in the range of unoxidized $(54 \%)$ and ozonolysis of canola oil (29\%) (Takhar et al., 2019) and was comparable to that in previous field studies (Paciga et al., 2016; Louvaris et al., 2017b). Higher $C^{*}$ of COA in summer than that in winter $\left(0.79 \mu \mathrm{g} \mathrm{m}^{-3}\right.$ vs. $0.59 \mu \mathrm{g} \mathrm{m}^{-3}$ ) indicated the less volatile properties likely due to the different cooking types. For example, barbecues are popular in summer but not in winter due to low ambient temperature. The SVOC contributed $67 \%$ to OPOA $\left(C^{*}=1.3 \mu \mathrm{g} \mathrm{m}^{-3}\right)$, which is in the range of $C^{*}$ of POA $(0.6-$ $1.4 \mu \mathrm{g} \mathrm{m}^{-3}$ ) at the urban site in winter. Overall, $33 \%$ of BBOA in Gucheng evaporated at $T>200^{\circ} \mathrm{C}$, which is comparable to BBOA in Xianghe, a rural site in the NCP (Qiao et al., 2020). The contribution of SVOC (51\%) in BBOA in Gucheng is lower than that measured in combustion chamber (80\%) (May et al., 2013a) but overall comparable with that in Centreville, AL (47\%) (Kostenidou et al., 2018). The differences in volatility distributions of BBOA were likely due to the variations in biomass fuels, combustion conditions and the extent of atmospheric aging (Ghadikolaei et al., 2020).

Similar to previous studies (Paciga et al., 2016; Kostenidou et al., 2018), LO-OOA was more volatile than MO-OOA in summer and winter, consistent with the fact that MO-OOA dominated OA at $T>200^{\circ} \mathrm{C}$. SVOC accounted for $64 \%$ and $70 \%$ of LO-OOA in winter and summer, respectively, with a lower $C^{*}$ in winter $\left(0.78 \mu \mathrm{g} \mathrm{m}^{-3}\right.$ vs. $1.58 \mathrm{\mu g} \mathrm{m}^{-3}$ ), highlighting that LO-OOA was more volatile in summer. Such seasonal differences can be explained by the different precursors and formation conditions of LO-OOA in two seasons, which are further supported by the differences in mass spectra. For example, the $f_{\mathrm{C}_{2} \mathrm{H}_{3} \mathrm{O}+} / f_{\mathrm{CO}_{2}+}$ ratio of LO-OOA in summer was higher than that in winter. It should be noted that the volatility of LO-OOA contradicted the results of thermograms which showed higher evaporation loss in winter than in summer (Fig. 2). While the longer 


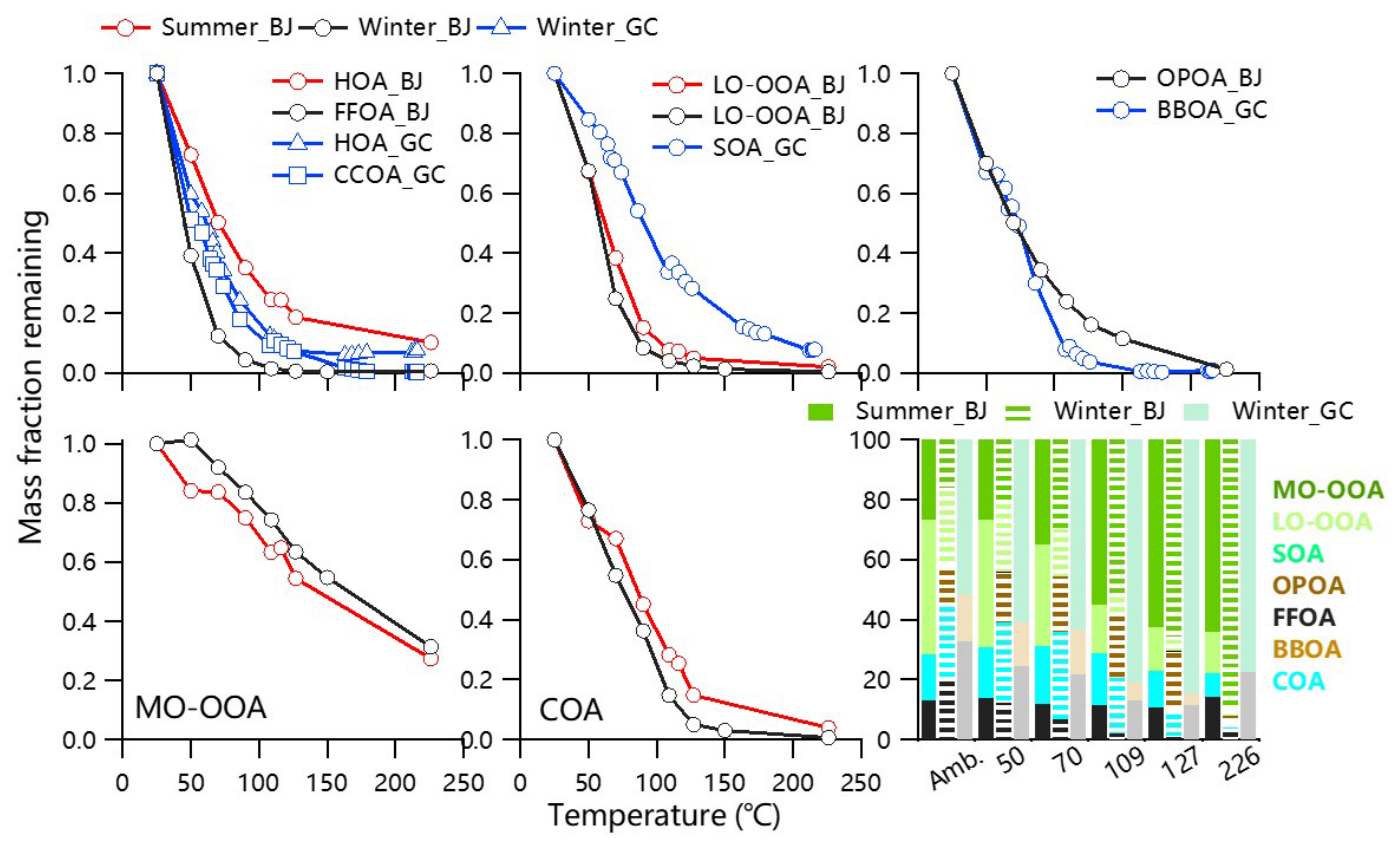

Figure 2. Thermograms of OA factors at both urban and rural sites. The mass fractions of OA factors as a function of TD temperature are also shown.

RT in winter is one of the causes, higher effective vaporization enthalpy $\left(136 \mathrm{~kJ} \mathrm{~mol}^{-1}\right.$ vs. $\left.157 \mathrm{~kJ} \mathrm{~mol}^{-1}\right)$ in winter is another reason. MO-OOA had comparably effective vaporization enthalpy $\left(56 \mathrm{~kJ} \mathrm{~mol}^{-1}\right.$ vs. $\left.58 \mathrm{~kJ} \mathrm{~mol}^{-1}\right)$ in summer and winter, yet showed more remaining loadings in winter at the same TD temperature with lower $C^{*}\left(0.49 \mu \mathrm{g} \mathrm{m}^{-3}\right.$ vs. $0.69 \mu \mathrm{g} \mathrm{m}^{-3}$ ). Note that LVOCs with $C^{*}=0.001 \mu \mathrm{g} \mathrm{m}^{-3}$, $0.01 \mu \mathrm{g} \mathrm{m}^{-3}$ and $0.1 \mu \mathrm{g} \mathrm{m}^{-3}$ contributed similarly to MOOOA in summer and winter (Fig. 3), indicating that the LVOCs of more aged SOA are independent of seasons. One reason is that the long-time aging process of $\mathrm{OA}$ in the atmosphere could lead to similar chemical compounds in summer and winter. Compared with the urban site, the remaining SOA after TD heating at the rural site fell into the range of LO-OOA and MO-OOA in Beijing, which consisted of $32 \%$ LVOC and $68 \%$ SVOC.

\subsection{Comparisons between volatile and nonvolatile compounds}

We further compared aerosol composition at different TD temperatures during three campaigns. Here we defined aerosol species remaining at $T>200^{\circ} \mathrm{C}$ as nonvolatile compounds, and those that evaporated at $T<90^{\circ} \mathrm{C}$ as volatile compounds. As shown in Fig. S4, signals for $m / z$ 100-180 (a potential indicator for oligomers) (Denkenberger et al., 2007) decreased with increasing TD temperature, suggesting that nonvolatile organics are unlikely to be oligomers formed within the heated TD. As indicated in Table S1, the mass loadings of nonvolatile sulfate and nitrate were comparable in Beijing in both summer $\left(\sim 0.39 \mu \mathrm{g} \mathrm{m}^{-3}\right)$ and winter $(0.15$ vs. $0.1 \mu \mathrm{g} \mathrm{m}^{-3}$ ). Comparatively, the ratio of nonvolatile $\mathrm{SO}_{4}$ to $\mathrm{NO}_{3}$ was 4.6 at the rural site during wintertime, highlighting the dominant role of sulfate in nonvolatile compounds. As shown in Fig. S5, sulfate between 100 and $300 \mathrm{~nm}$ accounted for $56 \%$ of total $\mathrm{SO}_{4}$ at $T>200{ }^{\circ} \mathrm{C}$, which is much higher than that in ambient air $(31 \%)$. One explanation is that the sulfate measured by HR-AMS has contributions from OSs, which showed a prominent peak below $320 \mathrm{~nm}$ (Kuang et al., 2015) with lower volatility than ammonium sulfate. Nonvolatile OA accounted for $51 \%$ of the total nonvolatile NR-PM ${ }_{1}$ in summer, which was lower than that in winter $(65 \%-72 \%)$. This result indicated that nonvolatile OA was more important in winter than summer, which was likely related to tar balls (Liu et al., 2021). Note that the contribution of nonvolatile OA to the total OA was comparable between summer and winter ( $6 \%-8 \%)$, yet lower than that observed in Athens (Gkatzelis et al., 2016) and water-soluble nonvolatile OA in Kanpur (Chakraborty et al., 2016), likely due to the different chemical compounds at various sites. The nonvolatile OA correlated well with equivalent black carbon (eBC) measured by a seven-wavelength Aethalometer (AE33) $\left(R^{2}=0.69-0.82\right)$, suggesting that it was well mixed with $\mathrm{eBC}$ during the aging processes in the atmosphere, consistent with the observations in Melpitz (Poulain et al., 2014) and London (Xu et al., 2016). The nonvolatile OA was dominated by MO-OOA (a factor related to aqueous processes; $\mathrm{Xu}$ et al., 2017), with a contribution of up to $90 \%$ in winter. This result suggests that the aqueous-phase processing played an important role in the formation of nonvolatile OA (e.g., diacids and oligomers), particularly during severe haze 

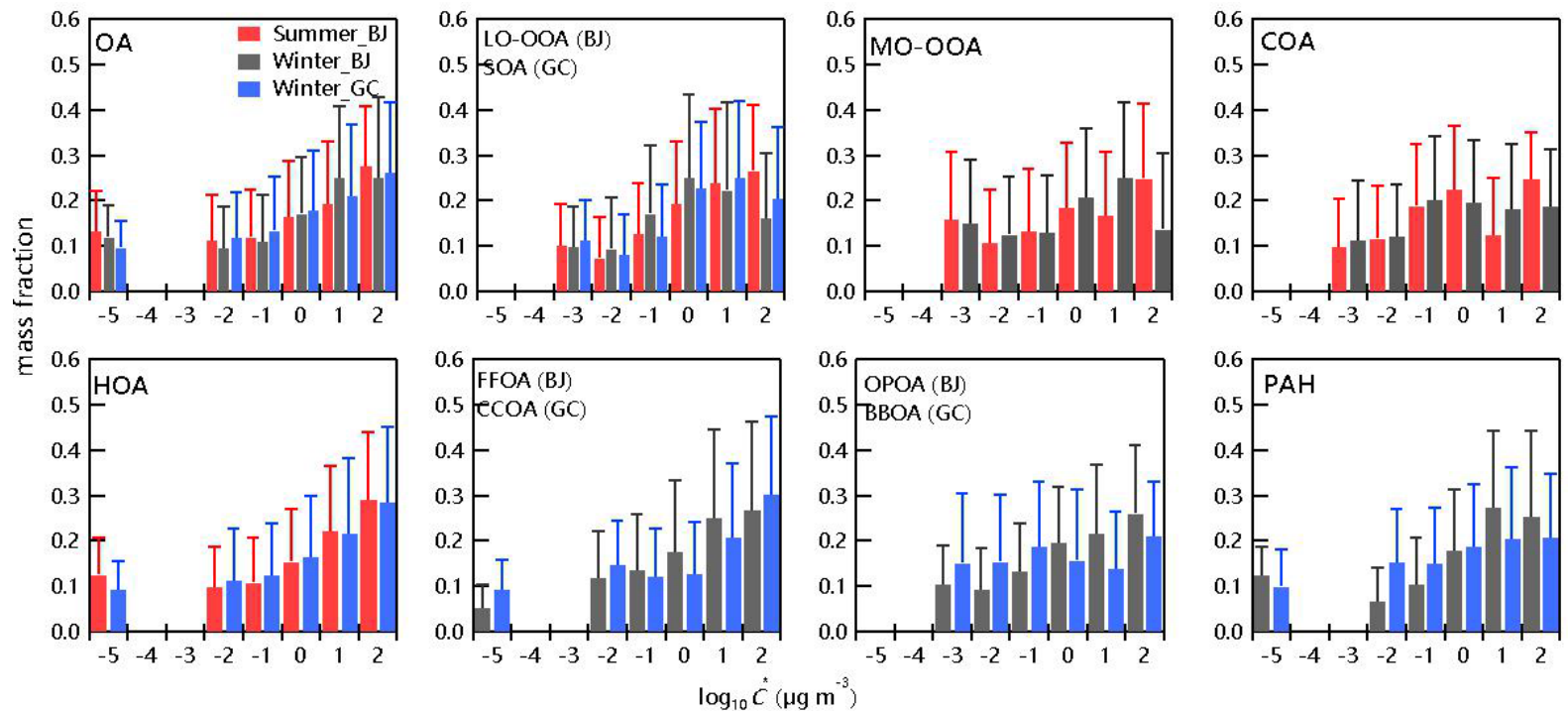

Figure 3. Predicted volatility distributions of OA, OA factors and PAH. The error bars are the uncertainties derived using the approach of Karnezi et al. (2014).
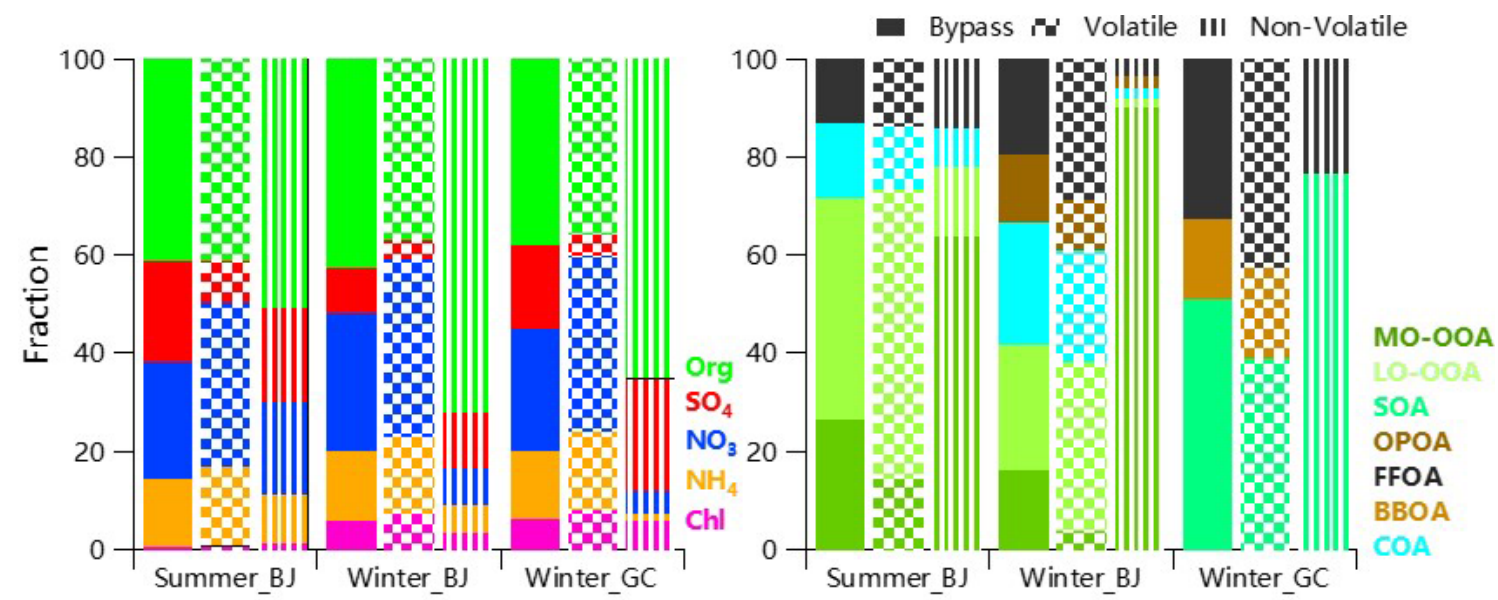

Figure 4. Average composition of total, volatile and nonvolatile PM and OA in Beijing and Gucheng.

episodes with high RH in winter in the NCP (Yu et al., 2014; Ortiz-Montalvo et al., 2012, 2014). Such results are also supported by the large increase in nonvolatile OA as elevated RH (Fig. S6), and the increases signal the fraction of $\mathrm{CHO}^{+}$ $(\mathrm{m} / \mathrm{z} 29)$ in the mass spectra $(7.2 \%-16.1 \%)$, a tracer ion related to aqueous processes (Zhao et al., 2019).

Different from nonvolatile components, the volatile compounds showed overall comparable contributions to the total volatile NR-PM 1 during three campaigns. Chl was an exception with a higher fraction in winter $(7 \%-8 \%)$ than in summer $(1 \%)$. The volatile NR-PM 1 was dominated by $\mathrm{NO}_{3}$ $(34 \%-36 \%)$ and $\mathrm{OA}(36 \%-41 \%)$ at both urban and rural sites, while the contribution of $\mathrm{SO}_{4}$ was small (4\%-9\%). We noticed that the composition of volatile OA was substantially different between summer and winter. As shown in Fig. 4, the volatile OA was dominated by SOA (74\%, mainly LOOOA) in summer and POA in winter (61\%-62\%), indicating that primary emissions played more important roles in volatile OA in winter. We noticed that FFOA was a dominant contributor of volatile POA at rural site, while COA made an important contribution to volatile POA at the urban site during wintertime.

\subsection{Volatility of SOA under different RH levels}

Figure 5 shows the thermograms of LO-OOA and MO-OOA at three different RH levels in summer and winter in Beijing. We found that the MFR of MO-OOA as a function of TD temperature was substantially different across different RH levels. MO-OOA shows more evaporative loss at higher $\mathrm{RH}$ levels $(\mathrm{RH}>70 \%)$ in both summer and winter, suggest- 


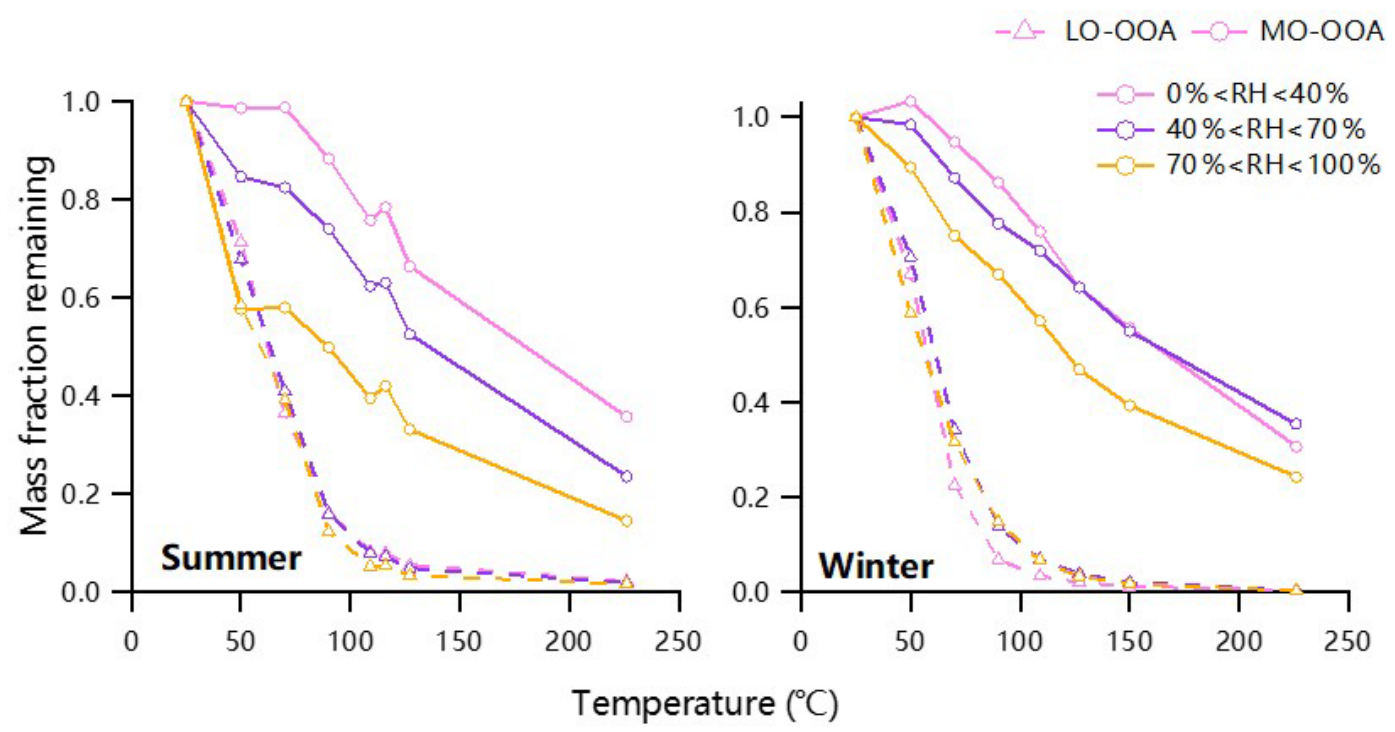

Figure 5. Thermograms of LO-OOA and MO-OOA during different RH levels in summer and winter in Beijing.

ing that MO-OOA compounds formed at high RH contained more relatively high-volatility compounds compared to that formed at lower RH. This result is consistent with the RH dependence of volatility for SOA in chamber experiments (Wilson et al., 2015; Zaveri et al., 2020). By comparison, LOOOA showed similar changes in MFR at different RH levels, particularly in summer, indicating that photochemical processing produced SOA with similar volatility despite the different chemical environment. Overall, our results highlight that the molecular composition of MO-OOA at different RH levels could be very different, yet their similar AMS mass spectra make it a challenge to separate them by PMF. For example, MO-OOA at low RH levels was more likely from long-time aging in the atmosphere or aqueous-phase processing on a regional scale that was transported to Beijing, while it could be associated more with local aqueous-phase processing at high RH levels with stagnant meteorological conditions. A recent study by Chen et al. (2020) further supported that the SOA factors identified by AMS-PMF can be further separated into more factors with different chemical processing by using molecular compositions from chemical ionization mass spectrometer with a filter inlet for gases and aerosols (FIGAERO-CIMS) measurements. Another possibility for the RH dependence of MO-OOA volatility is that the particle phase diffusivity limited the evaporation under dry conditions (Li and Shiraiwa, 2019; Yli-Juuti et al., 2017; Liu et al., 2016).

\subsection{Viscosity of $\mathrm{OA}$}

Figure 6 shows the two-dimensional volatility basis set (2D VBS) framework of $\mathrm{O} / \mathrm{C}$ vs. $\log _{10} C^{*}$ and the correlation

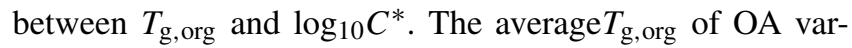
ied from 289.7 to $291.5 \mathrm{~K}$ in the NCP in summer and win-
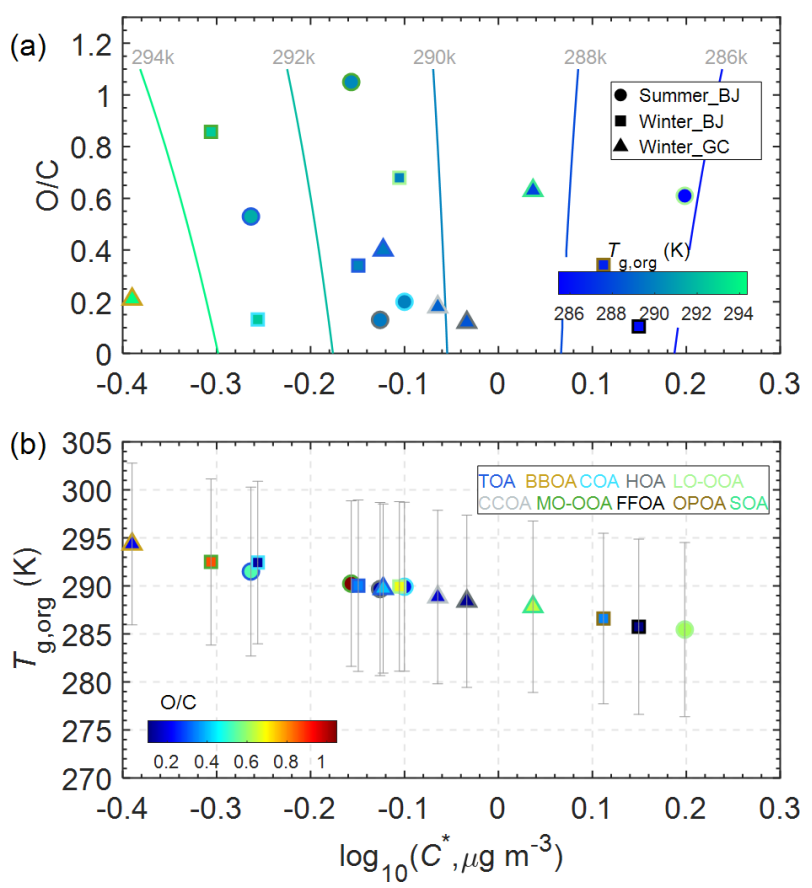

Figure 6. Predicted glass transition temperatures of organic aerosols under dry conditions $\left(T_{\mathrm{g}, \mathrm{org}}\right)$. The fill color of the markers represents $T_{\mathrm{g}, \text { org }}$ in (a) and $\mathrm{O} / \mathrm{C}$ in (b). The marker edge color indicates the OA components identified by PMF.

ter, which is in the range of the values estimated by chemical composition (Slade et al., 2019; Ditto et al., 2019) and chemical transport model simulations (Shiraiwa et al., 2017) in several field campaigns. In general, $T_{\mathrm{g}, \text { org }}$ of OA in summer in Beijing $(291.5 \mathrm{~K})$ is larger than that in winter (289.7$290.0 \mathrm{~K}$ ), yet it is lower than that in Europe and the US (Li 

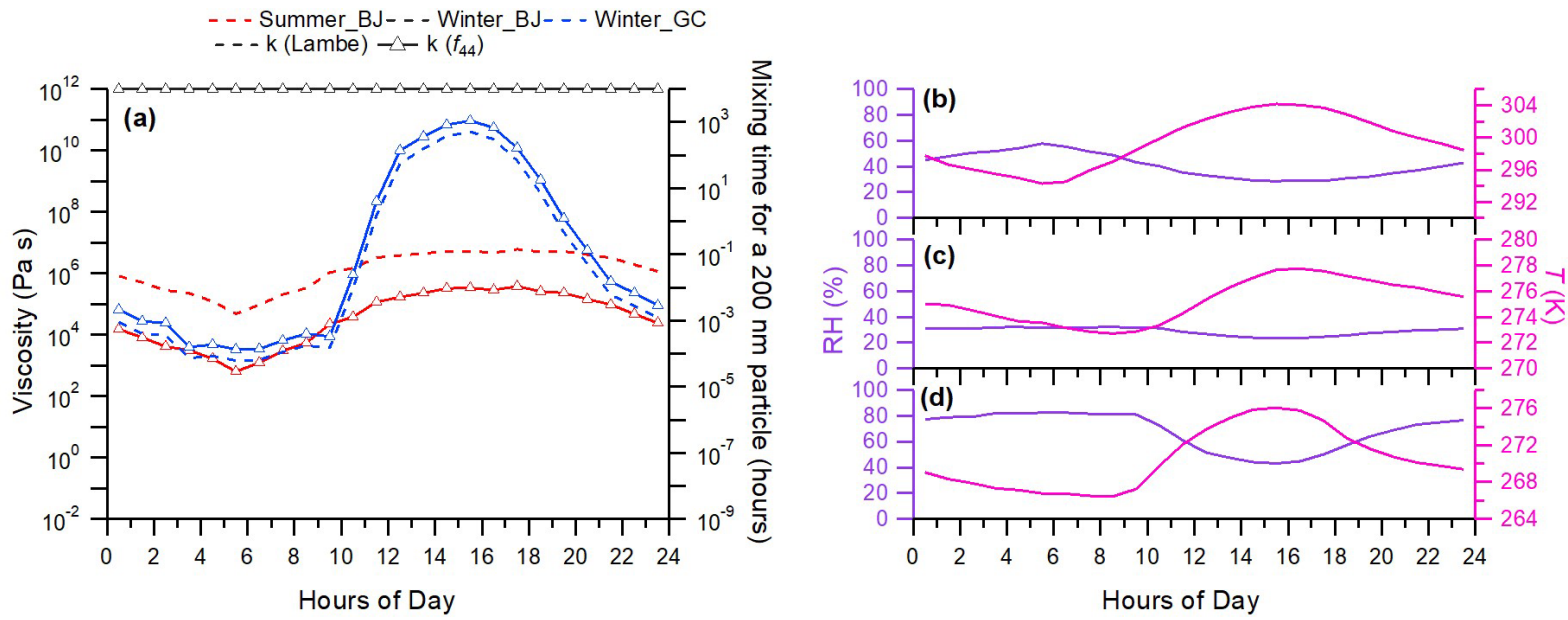

Figure 7. Diurnal variations in (a) viscosity of total OA and ambient RH and $T$ in Beijing in (b) summer and (c) winter. The diurnal cycles of ambient RH and $T$ in Gucheng during wintertime are shown in (d). Characteristic mixing timescales of organic molecules with a radius of $10^{-10} \mathrm{~m}$ within $200 \mathrm{~nm}$ particles are also shown on the right axis.

et al., 2020). Such differences are caused by the fact that highly volatile $\mathrm{OA}$ in China facilitates the partitioning of more SVOC into the particle phase compared to megacities in Europe and the US (Xu et al., 2019). The $T_{\mathrm{g}, \text { org }}$ of FFOA (or CCOA), a unique OA factor in the $\mathrm{NCP}$, is $285.8 \mathrm{~K}$ in Beijing and $288.9 \mathrm{~K}$ in Gucheng, which is overall slightly lower compared to HOA (288.4-289.7 K) in China. Such dif-

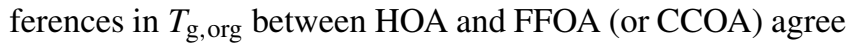
with the overall higher $C^{*}$ of FFOA. Even for the same OA factor, the differences in $T_{\mathrm{g}, \text { org }}$ exist at different sampling times and sites. For example, the $T_{\mathrm{g}, \text { org }}$ of BBOA in Gucheng $(294.4 \mathrm{~K})$ is lower than that in Athens, yet comparable to that in Mexico City ( $\mathrm{Li}$ et al., 2020), which is partly attributed to the different fuels, combustion conditions and oxidation during transport leading to the differences in volatility and oxidation degree. MO-OOA showed higher $T_{\mathrm{g} \text {, org }}$ than LOOOA in both summer (290.2 vs. $285.5 \mathrm{~K})$ and winter (292.5 vs. $289.9 \mathrm{~K}$ ) in Beijing, consistent with previous urban observations, e.g., Paris and Mexico City (Li et al., 2020).

Figure 7 shows diurnal variations in predicted viscosity of OA using measured $T$ and $\mathrm{RH}$ during three campaigns. The predicted viscosities using different kappa $(\kappa)$ values calculated by two methods correlate well with each other. The diurnal variation in viscosity is significantly affected by $T$ and $\mathrm{RH}$ and thus water associated with organics. Overall, in the winter of 2018 in Beijing, the OA occurred as a solid with the predicted viscosity $>10^{12} \mathrm{~Pa}$ due to low ambient temperature and RH. The mixing time is larger than $10^{3} \mathrm{~h}$; thus kinetically limited gas-particle partitioning needs to be considered when simulating SOA formation in winter in Beijing (Shiraiwa et al., 2011; Maclean et al., 2017; Li and Shiraiwa, 2019). We further explored the viscosity of OA as a function of RH in winter in Beijing and found that the viscosity of OA varied from $10^{2} \mathrm{~Pa}$ s to $10^{12} \mathrm{~Pa}$ s as RH was in the range of $40 \%-85 \%$, and it was less than $10^{2} \mathrm{Pas}$ at $\mathrm{RH}>85 \%$. These results suggest that OA particles in winter in Beijing would exist mainly in a semisolid phase and mostly as liquid at $\mathrm{RH}=40 \%-85 \%$ and $\mathrm{RH}>85 \%$, respectively. The viscosity of OA varies from $10^{2}$ to $10^{6} \mathrm{~Pa}$ in Beijing in summer and from $10^{3}$ to $10^{11} \mathrm{~Pa}$ s in Gucheng in winter, suggesting a semisolid phase throughout the day. The diurnal variations in predicted viscosity are characterized by increases in the afternoon in summer in Beijing and in winter in Gucheng, which are associated with diurnal variations in ambient $\mathrm{RH}$ and $T$. However, such diurnal variations in predicted viscosity are different from those in the Amazon region (Bateman et al., 2017) and Michigan (Slade et al., 2019), where enhanced viscosity at night due to the influence of biomass burning and the formation of high molar-mass organic compounds was observed. Note that the viscosity of OA in Gucheng shows a large afternoon peak, while it is small in Beijing in summer. Such differences are partly caused by the differences in diurnal variations in $\mathrm{RH}$ that are negatively related to the rebound fraction, an indicator of the viscosity (Liu et al., 2017). For example, as shown in Fig. 7, the RH shows a considerable and rapid decrease from $\sim 80 \%$ at $10: 00$ to $44 \%$ in the afternoon in Gucheng in winter, while the decreases in $\mathrm{RH}$ in Beijing during the same period of time are small $(<20 \%)$. It should be noted that we did not consider the mixing of OA and inorganic species in this work that can have influences on $T_{\mathrm{g}, \text { org }}$ and viscosity due to the water absorbed by inorganics (Pye et al., 2017).

\section{Conclusions}

A TD-AMS system was deployed at urban and rural sites in the NCP in summer and winter to investigate the volatility and viscosity of OA. Our results showed that the $C^{*}$ of 
OA in summer in Beijing $\left(0.55 \mu \mathrm{g} \mathrm{m}^{-3}\right)$ is lower than that in winter $\left(0.71-0.75 \mu \mathrm{g} \mathrm{m}^{-3}\right)$, indicating that $\mathrm{OA}$ was more volatile in winter. One reason was enhanced primary emissions from coal combustion and biomass burning with high volatility. The volatility distributions of OA varied differently among different OA factors and seasons. We found that the volatile properties of fossil-fuel-related OA were quite different between urban and rural sites, likely due to variations in oxidation during transport, different coal fuels and combustion conditions. The compositional differences between volatile and nonvolatile species were also evaluated. Our results showed that POA dominated volatile OA in winter $(61 \%-62 \%)$, while SOA contributed more to volatile OA in summer (74\%). Nonvolatile OA that is dominated by MOOOA was highly correlated with $\mathrm{BC}$ and increased as a function of RH, highlighting the potential formation of aqueousphase SOA on BC. We also found that the volatility of MOOOA was RH dependent, with higher volatility at higher RH levels. These results demonstrated that the composition and formation mechanisms of MO-OOA can be significantly different under different RH levels, yet such chemical information cannot be illustrated by PMF analysis of bulk OA. Future studies combining AMS and molecular-level characterization of OA can allow for deeper insights into the sources and properties of MO-OOA (Qi et al., 2019; Chen et al., 2020). The glass transition temperature and viscosity of OA were estimated using saturation mass concentration and the atomic $\mathrm{O} / \mathrm{C}$ ratio with the recently developed parameterization formula ( $\mathrm{Li}$ et al., 2020). Our results showed that the $T_{\mathrm{g}}$ of OA in summer in Beijing (291.5 K) is higher than that in winter (289.7-290.0 K), and both are overall lower than those in Europe and the US. The viscosity analysis suggested that OA occurred mainly as solid in winter in Beijing, and the mixing time can be as long as $10^{3} \mathrm{~h}$ because of low temperature and $\mathrm{RH}$, while it dominantly existed in a semisolid phase in Beijing in summer and Gucheng in winter. Our results have the significant implication that kinetically limited gas-particle partitioning needs to be considered in chemical transport models when simulating SOA formation in the NCP.

Data availability. The data in this study are available from the authors upon request (sunyele@mail.iap.ac.cn).

Supplement. The supplement related to this article is available online at: https://doi.org/10.5194/acp-21-5463-2021-supplement.

Author contributions. YS and WX designed the research. WX, CC, YQ, CX, ZL, JS, NM and WanX conducted the measurements. WX, CC, YQ, YL and ZZ analyzed the data. YL and ZZ supported the viscosity analysis, and EK and SNP supported the mass transfer model analysis. YL, PF, ZW, JZ, DRW and NLN reviewed and commented on the paper. WX and YS wrote the paper.

Competing interests. The authors declare that they have no conflict of interest.

Financial support. This research has been supported by the National Natural Science Foundation of China (grant nos. 41975170 and 91744207) and the Beijing Municipal Natural Science Foundation (grant no. 8202049).

Review statement. This paper was edited by Qiang Zhang and reviewed by two anonymous referees.

\section{References}

Bateman, A. P., Gong, Z., Harder, T. H., de Sá, S. S., Wang, B., Castillo, P., China, S., Liu, Y., O’Brien, R. E., Palm, B. B., Shiu, H. W., Cirino, G. G., Thalman, R., Adachi, K., Alexander, M. L., Artaxo, P., Bertram, A. K., Buseck, P. R., Gilles, M. K., Jimenez, J. L., Laskin, A., Manzi, A. O., Sedlacek, A., Souza, R. A. F., Wang, J., Zaveri, R., and Martin, S. T.: Anthropogenic influences on the physical state of submicron particulate matter over a tropical forest, Atmos. Chem. Phys., 17, 1759-1773, https://doi.org/10.5194/acp-17-1759-2017, 2017.

Canagaratna, M. R., Jimenez, J. L., Kroll, J. H., Chen, Q., Kessler, S. H., Massoli, P., Hildebrandt Ruiz, L., Fortner, E., Williams, L. R., Wilson, K. R., Surratt, J. D., Donahue, N. M., Jayne, J. T., and Worsnop, D. R.: Elemental ratio measurements of organic compounds using aerosol mass spectrometry: characterization, improved calibration, and implications, Atmos. Chem. Phys., 15, 253-272, https://doi.org/10.5194/acp-15-253-2015, 2015.

Chakraborty, A., Ervens, B., Gupta, T., and Tripathi, S. N.: Characterization of organic residues of size-resolved fog droplets and their atmospheric implications, J. Geophys. Res.-Atmos., 121, 4317-4332, https://doi.org/10.1002/2015jd024508, 2016.

Champion, W. M., Rothfuss, N. E., Petters, M. D., and Grieshop, A. P.: Volatility and Viscosity Are Correlated in Terpene Secondary Organic Aerosol Formed in a Flow Reactor, Environ. Sci. Technol. Lett., 6, 513-519, 2019.

Chen, C., Li, Z., Sun, J., Xu, W., Qiu, Y., Xie, C., He, Y., Li, Y., Li, J., Fu, P., Wang, Z., Worsnop, D. R., and Sun, Y.: Characterization of submicron aerosol in North China Plain (NCP), in preparation, 2021.

Chen, Q., Liu, Y., Donahue, N. M., Shilling, J. E., and Martin, S. T.: Particle-Phase Chemistry of Secondary Organic Material: Modeled Compared to Measured O : C and H : C Elemental Ratios Provide Constraints, Environ. Sci. Technol., 45, 4763-4770, https://doi.org/10.1021/es104398s, 2011.

Chen, Y., Xu, L., Humphry, T., Hettiyadura, A. P. S., Ovadnevaite, J., Huang, S., Poulain, L., Schroder, J. C., Campuzano-Jost, P., Jimenez, J. L., Herrmann, H., O’Dowd, C., Stone, E. A., and Ng, N. L.: Response of the Aerodyne Aerosol Mass Spectrometer to Inorganic Sulfates and Organosulfur Compounds: Applications 
in Field and Laboratory Measurements, Environ. Sci. Technol., 53, 5176-5186, https://doi.org/10.1021/acs.est.9b00884, 2019.

Chen, Y., Takeuchi, M., Nah, T., Xu, L., Canagaratna, M. R., Stark, H., Baumann, K., Canonaco, F., Prévôt, A. S. H., Huey, L. G., Weber, R. J., and Ng, N. L.: Chemical characterization of secondary organic aerosol at a rural site in the southeastern US: insights from simultaneous high-resolution time-of-flight aerosol mass spectrometer (HR-ToF-AMS) and FIGAERO chemical ionization mass spectrometer (CIMS) measurements, Atmos. Chem. Phys., 20, 8421-8440, https://doi.org/10.5194/acp-208421-2020, 2020.

Denkenberger, K. A., Moffet, R. C., Holecek, J. C., Rebotier, T. P., and Prather, K. A.: Real-Time, Single-Particle Measurements of Oligomers in Aged Ambient Aerosol Particles, Environ. Sci. Technol., 41, 5439-5446, https://doi.org/10.1021/es0703291, 2007.

DeRieux, W.-S., Li, Y., Lin, P., Laskin, J., Laskin, A., Bertram, A. K., Nizkorodov, S. A., and Shiraiwa, M.: Predicting the glass transition temperature and viscosity of secondary organic material using molecular composition, Atmos. Chem. Phys., 18, 6331-6351, https://doi.org/10.5194/acp-18-6331-2018, 2018.

Dette, H. P., Qi, M., Schröder, D. C., Godt, A., and Koop, T.: GlassForming Properties of 3-Methylbutane-1,2,3-tricarboxylic Acid and Its Mixtures with Water and Pinonic Acid, J. Phys. Chem. A, 118, 7024-7033, 2014.

Ditto, J. C., Joo, T., Khare, P., Sheu, R., Takeuchi, M., Chen, Y., Xu, W., Bui, A. A. T., Sun, Y., Ng, N. L., and Gentner, D. R.: Effects of Molecular-Level Compositional Variability in Organic Aerosol on Phase State and Thermodynamic Mixing Behavior, Environ. Sci. Technol., 53, 13009-13018, https://doi.org/10.1021/acs.est.9b02664, 2019.

Donahue, N. M., Epstein, S. A., Pandis, S. N., and Robinson, A. L.: A two-dimensional volatility basis set: 1. organic-aerosol mixing thermodynamics, Atmos. Chem. Phys., 11, 3303-3318, https://doi.org/10.5194/acp-11-3303-2011, 2011.

Dzepina, K., Arey, J., Marr, L. C., Worsnop, D. R., Salcedo, D., Zhang, Q., Onasch, T. B., Molina, L. T., Molina, M. J., and Jimenez, J. L.: Detection of particle-phase polycyclic aromatic hydrocarbons in Mexico City using an aerosol mass spectrometer, Int. J. Mass Spectrom., 263, 152-170, 2007.

Farmer, D. K., Matsunaga, A., Docherty, K. S., Surratt, J. D., Seinfeld, J. H., Ziemann, P. J., and Jimenez, J. L.: Response of an aerosol mass spectrometer to organonitrates and organosulfates and implications for atmospheric chemistry, P. Natl. Acad. Sci. USA, 107, 6670-6675, https://doi.org/10.1073/pnas.0912340107, 2010.

Ghadikolaei, M. A., Yung, K.-F., Cheung, C. S., Ho, S. S. H., and Wong, P. K.: Non-polar organic compounds, volatility and oxidation reactivity of particulate matter emitted from diesel engine fueled with ternary fuels in blended and fumigation modes, Chemosphere, 249, 126086, https://doi.org/10.1016/j.chemosphere.2020.126086, 2020.

Gkatzelis, G. I., Papanastasiou, D. K., Florou, K., Kaltsonoudis, C., Louvaris, E., and Pandis, S. N.: Measurement of nonvolatile particle number size distribution, Atmos. Meas. Tech., 9, 103-114, https://doi.org/10.5194/amt-9-103-2016, 2016.

Glasius, M. and Goldstein, A. H.: Recent Discoveries and Future Challenges in Atmospheric Organic
Chemistry, Environ. Sci. Technol., 50, 2754-2764, https://doi.org/10.1021/acs.est.5b05105, 2016.

Huang, W., Saathoff, H., Shen, X., Ramisetty, R., Leisner, T., and Mohr, C.: Seasonal characteristics of organic aerosol chemical composition and volatility in Stuttgart, Germany, Atmos. Chem. Phys., 19, 11687-11700, https://doi.org/10.5194/acp-19-116872019, 2019.

Huffman, J. A., Ziemann, P. J., Jayne, J. T., Worsnop, D. R., and Jimenez, J. L.: Development and characterization of a fast-stepping/scanning thermodenuder for chemically-resolved aerosol volatility measurements, Aerosol Sci. Tech., 42, 395407, 2008.

Huffman, J. A., Docherty, K. S., Aiken, A. C., Cubison, M. J., U1brich, I. M., DeCarlo, P. F., Sueper, D., Jayne, J. T., Worsnop, D. R., Ziemann, P. J., and Jimenez, J. L.: Chemically-resolved aerosol volatility measurements from two megacity field studies, Atmos. Chem. Phys., 9, 7161-7182, https://doi.org/10.5194/acp9-7161-2009, 2009.

Jayne, J. T., Leard, D. C., Zhang, X., Davidovits, P., Smith, K. A., Kolb, C. E., and Worsnop, D. R.: Development of an aerosol mass spectrometer for size and composition analysis of submicron particles, Aerosol Sci. Tech., 33, 49-70, 2000.

Jimenez, J. L., Canagaratna, M. R., Donahue, N. M., Prevot, A. S. H., Zhang, Q., Kroll, J. H., DeCarlo, P. F., Allan, J. D., Coe, H., Ng, N. L., Aiken, A. C., Docherty, K. S., Ulbrich, I. M., Grieshop, A. P., Robinson, A. L., Duplissy, J., Smith, J. D., Wilson, K. R., Lanz, V. A., Hueglin, C., Sun, Y. L., Tian, J., Laaksonen, A., Raatikainen, T., Rautiainen, J., Vaattovaara, P., Ehn, M., Kulmala, M., Tomlinson, J. M., Collins, D. R., Cubison, M. J., E, Dunlea, J., Huffman, J. A., Onasch, T. B., Alfarra, M. R., Williams, P. I., Bower, K., Kondo, Y., Schneider, J., Drewnick, F., Borrmann, S., Weimer, S., Demerjian, K., Salcedo, D., Cottrell, L., Griffin, R., Takami, A., Miyoshi, T., Hatakeyama, S., Shimono, A., Sun, J. Y., Zhang, Y. M., Dzepina, K., Kimmel, J. R., Sueper, D., Jayne, J. T., Herndon, S. C., Trimborn, A. M., Williams, L. R., Wood, E. C., Middlebrook, A. M., Kolb, C. E., Baltensperger, U., and Worsnop, D. R.: Evolution of organic aerosols in the atmosphere, Science, 326, 1525-1529, https://doi.org/10.1126/science.1180353, 2009.

Karnezi, E., Riipinen, I., and Pandis, S. N.: Measuring the atmospheric organic aerosol volatility distribution: a theoretical analysis, Atmos. Meas. Tech., 7, 2953-2965, https://doi.org/10.5194/amt-7-2953-2014, 2014.

Kostenidou, E., Karnezi, E., Hite Jr., J. R., Bougiatioti, A., Cerully, K., Xu, L., Ng, N. L., Nenes, A., and Pandis, S. N.: Organic aerosol in the summertime southeastern United States: components and their link to volatility distribution, oxidation state and hygroscopicity, Atmos. Chem. Phys., 18, 5799-5819, https://doi.org/10.5194/acp-18-5799-2018, 2018.

Kuang, B.-Y., Lin, P., Hu, M., and Yu, J.: Aerosol Size Distribution Characteristics of Organosulfates in the Pearl River Delta Region, China, Atmos. Environ., 130, 23-35, https://doi.org/10.1016/j.atmosenv.2015.09.024, 2015.

Kuang, Y., He, Y., Xu, W., Yuan, B., Zhang, G., Ma, Z., Wu, C., Wang, C., Wang, S., Zhang, S., Tao, J., Ma, N., Su, H., Cheng, Y., Shao, M., and Sun, Y.: Photochemical Aqueous-Phase Reactions Induce Rapid Daytime Formation of Oxygenated Organic Aerosol on the North China Plain, Environ. Sci. Technol., 54, 3849-3860, https://doi.org/10.1021/acs.est.9b06836, 2020. 
Lambe, A. T., Onasch, T. B., Massoli, P., Croasdale, D. R., Wright, J. P., Ahern, A. T., Williams, L. R., Worsnop, D. R., Brune, W. H., and Davidovits, P.: Laboratory studies of the chemical composition and cloud condensation nuclei $(\mathrm{CCN})$ activity of secondary organic aerosol (SOA) and oxidized primary organic aerosol (OPOA), Atmos. Chem. Phys., 11, 8913-8928, https://doi.org/10.5194/acp-11-8913-2011, 2011.

Lee, B.-H., Pierce, J. R., Engelhart, G. J., and Pandis, S. N.: Volatility of secondary organic aerosol from the ozonolysis of monoterpenes, Atmos. Environ., 45, 2443-2452, https://doi.org/10.1016/j.atmosenv.2011.02.004, $2011 \mathrm{a}$.

Lee, B.-H., Pierce, J. R., Engelhart, G. J., and Pandis, S. N.: Volatility of secondary organic aerosol from the ozonolysis of monoterpenes, Atmos. Environ., 45, 2443-2452, https://doi.org/10.1016/j.atmosenv.2011.02.004, 2011b.

Li, Y. and Shiraiwa, M.: Timescales of secondary organic aerosols to reach equilibrium at various temperatures and relative humidities, Atmos. Chem. Phys., 19, 5959-5971, https://doi.org/10.5194/acp-19-5959-2019, 2019.

Li, Y., Day, D. A., Stark, H., Jimenez, J. L., and Shiraiwa, M.: Predictions of the glass transition temperature and viscosity of organic aerosols from volatility distributions, Atmos. Chem. Phys., 20, 8103-8122, https://doi.org/10.5194/acp-208103-2020, 2020.

Liu, L., Zhang, J., Zhang, Y., Wang, Y., Xu, L., Yuan, Q., Liu, D., Sun, Y., Fu, P., Shi, Z., and Li, W.: Persistent residential burningrelated primary organic particles during wintertime hazes in North China: insights into their aging and optical changes, Atmos. Chem. Phys., 21, 2251-2265, https://doi.org/10.5194/acp21-2251-2021, 2021.

Liu, P., Li, Y. J., Wang, Y., Bateman, A. P., Zhang, Y., Gong, Z., Bertram, A. K., and Martin, S. T.: Highly Viscous States Affect the Browning of Atmospheric Organic Particulate Matter, ACS Central Sci., 4, 207-215, https://doi.org/10.1021/acscentsci.7b00452, 2018.

Liu, P. F., Li, Y. J., Wang, Y., Gilles, M. K., Zaveri, R. A., Bertram, A. K., and Martin, S. T.: Lability of secondary organic particulate matter, P. Natl. Acad. Sci. USA, 113, 12643-12648, https://doi.org/10.1073/pnas.1603138113, 2016.

Liu, Y., Wu, Z., Wang, Y., Xiao, Y., Gu, F., Zheng, J., Tan, T., Shang, D., Wu, Y., and Zeng, L.: Submicrometer particles are in the liquid state during heavy haze episodes in the urban atmosphere of Beijing, China, Environ. Sci. Tech. Let., 4, 427-432, 2017.

Liu, Y., Wu, Z., Huang, X., Shen, H., Bai, Y., Qiao, K., Meng, X., Hu, W., Tang, M., and He, L.: Aerosol Phase State and Its Link to Chemical Composition and Liquid Water Content in a Subtropical Coastal Megacity, Environ. Sci. Technol., 53, 5027-5033, https://doi.org/10.1021/acs.est.9b01196, 2019.

Louvaris, E. E., Florou, K., Karnezi, E., Papanastasiou, D. K., Gkatzelis, G. I., and Pandis, S. N.: Volatility of source apportioned wintertime organic aerosol in the city of Athens, Atmos. Environ., 158, 138-147, https://doi.org/10.1016/j.atmosenv.2017.03.042, 2017a.

Louvaris, E. E., Karnezi, E., Kostenidou, E., Kaltsonoudis, C., and Pandis, S. N.: Estimation of the volatility distribution of organic aerosol combining thermodenuder and isothermal dilution measurements, Atmos. Meas. Tech., 10, 3909-3918, https://doi.org/10.5194/amt-10-3909-2017, 2017 b.
Maclean, A. M., Butenhoff, C. L., Grayson, J. W., Barsanti, K., Jimenez, J. L., and Bertram, A. K.: Mixing times of organic molecules within secondary organic aerosol particles: a global planetary boundary layer perspective, Atmos. Chem. Phys., 17, 13037-13048, https://doi.org/10.5194/acp-17-130372017, 2017.

Massoli, P., Onasch, T. B., Cappa, C. D., Nuamaan, I., Hakala, J., Hayden, K., Li, S.-M., Sueper, D. T., Bates, T. S., Quinn, P. K., Jayne, J. T., and Worsnop, D. R.: Characterization of black carbon-containing particles from soot particle aerosol mass spectrometer measurements on the R/V Atlantis during CalNex 2010, J. Geophys. Res.-Atmos., 120, 2575-2593, https://doi.org/10.1002/2014jd022834, 2015.

Matsui, H., Koike, M., Takegawa, N., Kondo, Y., Griffin, R. J., Miyazaki, Y., Yokouchi, Y., and Ohara, T.: Secondary organic aerosol formation in urban air: Temporal variations and possible contributions from unidentified hydrocarbons, J. Geophys. Res.Atmos., 114, D04201, https://doi.org/10.1029/2008JD010164, 2009.

May, A. A., Levin, E. J., Hennigan, C. J., Riipinen, I., Lee, T., Collett Jr., J. L., Jimenez, J. L., Kreidenweis, S. M., and Robinson, A. L.: Gas-particle partitioning of primary organic aerosol emissions: 3. Biomass burning, J. Geophys. Res.-Atmos., 118, 11327-311338, https://doi.org/10.1002/jgrd.50828, 2013a.

May, A. A., Presto, A. A., Hennigan, C. J., Nguyen, N. T., Gordon, T. D., and Robinson, A. L.: Gas-Particle Partitioning of Primary Organic Aerosol Emissions: (2) Diesel Vehicles, Environ. Sci. Technol., 47, 8288-8296, https://doi.org/10.1021/es400782j, 2013b.

May, A. A., Presto, A. A., Hennigan, C. J., Nguyen, N. T., Gordon, T. D., and Robinson, A. L.: Gas-particle partitioning of primary organic aerosol emissions: (1) Gasoline vehicle exhaust, Atmos. Environ., 77, 128-139, https://doi.org/10.1016/j.atmosenv.2013.04.060, 2013c.

Mei, F., Setyan, A., Zhang, Q., and Wang, J.: CCN activity of organic aerosols observed downwind of urban emissions during CARES, Atmos. Chem. Phys., 13, 12155-12169, https://doi.org/10.5194/acp-13-12155-2013, 2013.

Ni, H. Y., Huang, R. J., Cao, J. J., Dai, W. T., Zhou, J. M., Deng, H. Y., Aerts-Bijma, A., Meijer, H. A. J., and Dusek, U.: High contributions of fossil sources to more volatile organic aerosol, Atmos. Chem. Phys., 19, 10405-10422, https://doi.org/10.5194/acp-1910405-2019, 2019.

Ortiz-Montalvo, D. L., Lim, Y. B., Perri, M. J., Seitzinger, S. P., and Turpin, B. J.: Volatility and Yield of Glycolaldehyde SOA Formed through Aqueous Photochemistry and Droplet Evaporation, Aerosol Sci. Tech., 46, 1002-1014, https://doi.org/10.1080/02786826.2012.686676, 2012.

Ortiz-Montalvo, D. L., Häkkinen, S. A., Schwier, A. N., Lim, Y. B., McNeill, V. F., and Turpin, B. J.: Ammonium addition (and aerosol $\mathrm{pH}$ ) has a dramatic impact on the volatility and yield of glyoxal secondary organic aerosol, Environ. Sci. Technol., 48, 255-262, 2014.

Paciga, A., Karnezi, E., Kostenidou, E., Hildebrandt, L., Psichoudaki, M., Engelhart, G. J., Lee, B.-H., Crippa, M., Prevot, A. S. H., Baltensperger, U., and Pandis, S. N.: Volatility of organic aerosol and its components in the megacity of Paris, Atmos. Chem. Phys., 16, 2013-2023, https://doi.org/10.5194/acp16-2013-2016, 2016. 
Poulain, L., Birmili, W., Canonaco, F., Crippa, M., Wu, Z. J., Nordmann, S., Spindler, G., Prevot, A. S. H., Wiedensohler, A., and Herrmann, H.: Chemical mass balance of 300 degrees $\mathrm{C}$ non-volatile particles at the tropospheric research site Melpitz, Germany, Atmos. Chem. Phys., 14, 10145-10162, https://doi.org/10.5194/acp-14-10145-2014, 2014.

Pye, H. O. T., Murphy, B. N., Xu, L., Ng, N. L., Carlton, A. G., Guo, H., Weber, R., Vasilakos, P., Appel, K. W., Budisulistiorini, S. H., Surratt, J. D., Nenes, A., Hu, W., Jimenez, J. L., Isaacman-VanWertz, G., Misztal, P. K., and Goldstein, A. H.: On the implications of aerosol liquid water and phase separation for organic aerosol mass, Atmos. Chem. Phys., 17, 343-369, https://doi.org/10.5194/acp-17-343-2017, 2017.

Qi, L., Chen, M., Stefenelli, G., Pospisilova, V., Tong, Y., Bertrand, A., Hueglin, C., Ge, X., Baltensperger, U., Prévôt, A. S. H., and Slowik, J. G.: Organic aerosol source apportionment in Zurich using an extractive electrospray ionization time-of-flight mass spectrometer (EESI-TOF-MS) - Part 2: Biomass burning influences in winter, Atmos. Chem. Phys., 19, 8037-8062, https://doi.org/10.5194/acp-19-8037-2019, 2019.

Qiao, Z., Li-Ming, C., Meng-Xue, T., Xiao-Feng, H., Eri, S., and He, L. Y.: Characterization of organic aerosol at a rural site in North China Plain: sources, volatility and organonitrates, Adv. Atmos. Sci., in press, https://doi.org/10.1007/s00376-020-01272, 2021.

Saha, P. K., Khlystov, A., Yahya, K., Zhang, Y., Xu, L., Ng, N. L., and Grieshop, A. P.: Quantifying the volatility of organic aerosol in the southeastern US, Atmos. Chem. Phys., 17, 501520, https://doi.org/10.5194/acp-17-501-2017, 2017.

Saha, P. K., Khlystov, A., and Grieshop, A. P.: Downwind evolution of the volatility and mixing state of near-road aerosols near a US interstate highway, Atmos. Chem. Phys., 18, 2139-2154, https://doi.org/10.5194/acp-18-2139-2018, 2018.

Schervish, M. and Donahue, N. M.: Peroxy radical chemistry and the volatility basis set, Atmos. Chem. Phys., 20, 1183-1199, https://doi.org/10.5194/acp-20-1183-2020, 2020.

Shiraiwa, M. and Seinfeld, J. H.: Equilibration timescale of atmospheric secondary organic aerosol partitioning, Geophys. Res. Lett., 39, L24801, https://doi.org/10.1029/2012g1054008, 2012.

Shiraiwa, M., Ammann, M., Koop, T., and Poschl, U.: Gas uptake and chemical aging of semisolid organic aerosol particles, P. Natl. Acad. Sci. USA, 108, 11003-11008, https://doi.org/10.1073/pnas.1103045108, 2011.

Shiraiwa, M., Li, Y., Tsimpidi, A. P., Karydis, V. A., Berkemeier, T., Pandis, S. N., Lelieveld, J., Koop, T., and Poschl, U.: Global distribution of particle phase state in atmospheric secondary organic aerosols, Nat. Commun., 8, 15002, https://doi.org/10.1038/ncomms15002, 2017.

Shrivastava, M., Cappa, C. D., Fan, J., Goldstein, A. H., Guenther, A. B., Jimenez, J. L., Kuang, C., Laskin, A., Martin, S. T., Ng, N. L., Petaja, T., Pierce, J. R., Rasch, P. J., Roldin, P., Seinfeld, J. H., Shilling, J., Smith, J. N., Thornton, J. A., Volkamer, R., Wang, J., Worsnop, D. R., Zaveri, R. A., Zelenyuk, A., and Zhang, Q.: Recent advances in understanding secondary organic aerosol: Implications for global climate forcing, Rev. Geophys., 55, 509559, https://doi.org/10.1002/2016rg000540, 2017.

Slade, J. H., Ault, A. P., Bui, A., Ditto, J., Lei, Z., Bondy, A. L., Olson, N., Cook, R., Desrochers, S., and Harvey, R.: Bouncier Particles at Night: Biogenic Secondary Organic Aerosol Chem- istry and Sulfate Drive Diel Variations in the Aerosol Phase in a Mixed Forest, Environ. Sci. Technol., 53, 4977-4987, 2019.

Stark, H., Yatavelli, R. L. N., Thompson, S. L., Kang, H., Krechmer, J. E., Kimmel, J. R., Palm, B. B., Hu, W., Hayes, P. L., Day, D. A., Campuzano-Jost, P., Canagaratna, M. R., Jayne, J. T., Worsnop, D. R., and Jimenez, J. L.: Impact of Thermal Decomposition on Thermal Desorption Instruments: Advantage of Thermogram Analysis for Quantifying Volatility Distributions of Organic Species, Environ. Sci. Technol., 51, 8491-8500, https://doi.org/10.1021/acs.est.7b00160, 2017.

Sun, Y., He, Y., Kuang, Y., Xu, W., Song, S., Ma, N., Tao, J., Cheng, P., Wu, C., Su, H., Cheng, Y., Xie, C., Chen, C., Lei, L., Qiu, Y., $\mathrm{Fu}$, P., Croteau, P., and Worsnop, D. R.: Chemical Differences Between $\mathrm{PM}_{1}$ and $\mathrm{PM}_{2.5}$ in Highly Polluted Environment and Implications in Air Pollution Studies, Geophys. Res. Lett., 47, e2019GL086288, https://doi.org/10.1029/2019g1086288, 2020.

Takhar, M., Stroud, C. A., and Chan, A. W. H.: Volatility Distribution and Evaporation Rates of Organic Aerosol from Cooking Oils and their Evolution upon Heterogeneous Oxidation, ACS Earth Space Chem., 3, 1717-1728, https://doi.org/10.1021/acsearthspacechem.9b00110, 2019.

Tan, W., Li, C., Liu, Y., Meng, X., Wu, Z., Kang, L., and Zhu, T.: Potential of Polarization Lidar to Profile the Urban Aerosol Phase State during Haze Episodes, Environ. Sci. Tech. Lett., 7, 54-59, https://doi.org/10.1021/acs.estlett.9b00695, 2020.

Ulbrich, I. M., Canagaratna, M. R., Zhang, Q., Worsnop, D. R., and Jimenez, J. L.: Interpretation of organic components from Positive Matrix Factorization of aerosol mass spectrometric data, Atmos. Chem. Phys., 9, 2891-2918, https://doi.org/10.5194/acp-92891-2009, 2009.

Wang, Y., Wang, Q., Ye, J., Yan, M., Qin, Q., Prévôt, A. S. H., and Cao, J.: A Review of Aerosol Chemical Composition and Sources in Representative Regions of China during Wintertime, Atmosphere, 10, 277, https://doi.org/10.3390/atmos10050277, 2019.

Wang, Z. B., Birmili, W., Hamed, A., Wehner, B., Spindler, G., Pei, X. Y., Wu, Z. J., Cheng, Y. F., Su, H., and Wiedensohler, A.: Contributions of volatile and nonvolatile compounds (at $300^{\circ} \mathrm{C}$ ) to condensational growth of atmospheric nanoparticles: An assessment based on 8.5 years of observations at the Central Europe background site Melpitz, J. Geophys. Res.-Atmos., 122, 485497, https://doi.org/10.1002/2016jd025581, 2017.

Wehner, B., Philippin, S., Wiedensohler, A., Scheer, V., and Vogt, R.: Variability of non-volatile fractions of atmospheric aerosol particles with traffic influence, Atmos. Environ., 38, 6081-6090, 2004.

Wilson, J., Imre, D., Beranek, J., Shrivastava, M., and Zelenyuk, A.: Evaporation Kinetics of Laboratory-Generated Secondary Organic Aerosols at Elevated Relative Humidity, Environ. Sci. Technol., 49, 243-249, https://doi.org/10.1021/es505331d, 2015.

Xu, L., Williams, L. R., Young, D. E., Allan, J. D., Coe, H., Massoli, P., Fortner, E., Chhabra, P., Herndon, S., Brooks, W. A., Jayne, J. T., Worsnop, D. R., Aiken, A. C., Liu, S., Gorkowski, K., Dubey, M. K., Fleming, Z. L., Visser, S., Prevot, A. S. H., and Ng, N. L.: Wintertime aerosol chemical composition, volatility, and spatial variability in the greater London area, Atmos. Chem. Phys., 16, 1139-1160, https://doi.org/10.5194/acp-16-1139-2016, 2016.

Xu, W., Han, T., Du, W., Wang, Q., Chen, C., Zhao, J., Zhang, Y., Li, J., Fu, P., Wang, Z., Worsnop, D. R., and 
Sun, Y.: Effects of Aqueous-Phase and Photochemical Processing on Secondary Organic Aerosol Formation and Evolution in Beijing, China, Environ. Sci. Technol., 51, 762-770, https://doi.org/10.1021/acs.est.6b04498, 2017.

Xu, W., Xie, C., Karnezi, E., Zhang, Q., Wang, J., Pandis, S. N., Ge, X., Zhang, J., An, J., Wang, Q., Zhao, J., Du, W., Qiu, Y., Zhou, W., He, Y., Li, Y., Li, J., Fu, P., Wang, Z., Worsnop, D. R., and Sun, Y.: Summertime aerosol volatility measurements in Beijing, China, Atmos. Chem. Phys., 19, 10205-10216, https://doi.org/10.5194/acp-19-10205-2019, 2019.

Xu, W., Takeuchi, M., Chen, C., Qiu, Y., Xie, C., Xu, W., Ma, N., Worsnop, D. R., Ng, N. L., and Sun, Y.: Estimation of particulate organic nitrates from thermodenuder-aerosol mass spectrometer measurements in North China Plain, Atmos. Meas. Tech. Discuss. [preprint], https://doi.org/10.5194/amt-2020-474, in review, 2020.

Xu, W. Q., Sun, Y. L., Chen, C., Du, W., Han, T. T., Wang, Q. Q., Fu, P. Q., Wang, Z. F., Zhao, X. J., Zhou, L. B., Ji, D. S., Wang, P. C., and Worsnop, D. R.: Aerosol composition, oxidation properties, and sources in Beijing: results from the 2014 Asia-Pacific Economic Cooperation summit study, Atmos. Chem. Phys., 15, 13681-13698, https://doi.org/10.5194/acp-1513681-2015, 2015.

Yli-Juuti, T., Pajunoja, A., Tikkanen, O.-P., Buchholz, A., Faiola, C., Vaisanen, O., Hao, L., Kari, E., Perakyla, O., Garmash, O., Shiraiwa, M., Ehn, M., Lehtinen, K., and Virtanen, A.: Factors controlling the evaporation of secondary organic aerosol from alpha-pinene ozonolysis, Geophys. Res. Lett., 44, 2562-2570, https://doi.org/10.1002/2016gl072364, 2017.

Yu, K., Zhu, Q., Du, K., and Huang, X. F.: Characterization of nighttime formation of particulate organic nitrates based on high-resolution aerosol mass spectrometry in an urban atmosphere in China, Atmos. Chem. Phys., 19, 5235-5249, https://doi.org/10.5194/acp-19-5235-2019, 2019.
Yu, L., Smith, J., Laskin, A., Anastasio, C., Laskin, J., and Zhang, Q.: Chemical characterization of SOA formed from aqueousphase reactions of phenols with the triplet excited state of carbonyl and hydroxyl radical, Atmos. Chem. Phys., 14, 1380113816, https://doi.org/10.5194/acp-14-13801-2014, 2014.

Zaveri, R. A., Shilling, J. E., Zelenyuk, A., Zawadowicz, M. A., Suski, K., China, S., Bell, D. M., Veghte, D., and Laskin, A.: Particle-Phase Diffusion Modulates Partitioning of Semivolatile Organic Compounds to Aged Secondary Organic Aerosol, Environ. Sci. Technol., 54, 2595-2605, https://doi.org/10.1021/acs.est.9b05514, 2020.

Zhang, Y., Nichman, L., Spencer, P., Jung, J. I., Lee, A., Heffernan, B. K., Gold, A., Zhang, Z. F., Chen, Y. Z., Canagaratna, M. R., Jayne, J. T., Worsnop, D. R., Onasch, T. B., Surratt, J. D., Chandler, D., Davidovits, P., and Kolb, C. E.: The Cooling Rate- and Volatility-Dependent Glass-Forming Properties of Organic Aerosols Measured by Broadband Dielectric Spectroscopy, Environ. Sci. Technol., 53, 12366-12378, https://doi.org/10.1021/acs.est.9b03317, 2019.

Zhao, J., Qiu, Y. M., Zhou, W., Xu, W. Q., Wang, J. F., Zhang, Y. J., Li, L. J., Xie, C. H., Wang, Q. Q., Du, W., Worsnop, D. R., Canagaratna, M. R., Zhou, L. B., Ge, X. L., Fu, P. Q., Li, J., Wang, Z. F., Donahue, N. M., and Sun, Y. L.: Organic Aerosol Processing During Winter Severe Haze Episodes in Beijing, J. Geophys. Res.-Atmos., 124, 1024810263, https://doi.org/10.1029/2019jd030832, 2019.

Zhou, W., Xu, W., Kim, H., Zhang, Q., Fu, P., Worsnop, D. R., and Sun, Y.: A review of aerosol chemistry in Asia: insights from aerosol mass spectrometer measurements, Environ. Sci. Proc. Imp., 22, 1616-1653, https://doi.org/10.1039/d0em00212g, 2020. 